\title{
A taxonomic revision of Grevillea arenaria and Grevillea obtusiflora (Proteaceae: Grevilleoideae)
}

\author{
Peter M. Olde \& Neil R. Marriott
}

\begin{abstract}
Olde, Peter M. ${ }^{1}$ \& Marriott, Neil R. ${ }^{2},\left({ }^{1} 138\right.$ Fowler Rd, Illawong, NSW 2234, Australia; ${ }^{2}$ PO Box 107 , Stawell VIC 3377 Australia). 1994. A taxonomic revision of Grevillea arenaria and Grevillea obtusiflora (Proteaceae: Grevilleoideae). Telopea 5(4): 711-733. Grevillea arenaria R. Br. and Grevillea obtusiflora R. Br. are revised resulting in recognition of five new species (G. banyabba P. Olde \& N. Marriott, G. guthrieana P. Olde \& N. Marriott, G. masonii P. Olde \& N. Marriott, G. quadricauda P. Olde \& N. Marriott and G. rhizomatosa P. Olde \& N. Marriott). With the exception of G, guthrieana, which is currently included in G. obtusiflora subsp. granulifera McGillivray, all newly described species were included in G. arenaria subsp. arenaria by McGillivray (1993). Grevillea arenaria var. canescens ( $R$. Br.) Bentham is reinstated and ranked at subspecific rank (G. arenaria R.Br. subsp. canescens (R.Br.) P. Olde \& N. Marriott). G. montana R. Br. is reinstated at specific rank [currently G. arenaria subsp. montana (R. Br.) McGillivray]. All currently accepted subspecies of $G$. obtusiflora are recognised at specific rank; subsp. kedumbensis MoGillivray and subsp. granulifera McGillivray are recognised respectively as G. kedumbensis (McGillivray) P. Olde \& N. Marriott and G. granulifera (McGillivray) P. Olde \& N. Marriott. A key to the whole group and descriptions of all new taxa are provided, as well as notes on affinities and distribution. Infraspecific keys are also provided where appropriate. All taxa have been seen in the field.
\end{abstract}

\section{Introduction}

Grevillea arenaria, Grevillea canescens, Grevillea montana and Grevillea obtusiflora were first described by Robert Brown $(1810,1830)$. These species are phenetically similar and almost certainly form part of a monophyletic group that includes among others G. mucronulata R. Br. and G. alpina Lindl. They belong to Section 2 Ptychocarpa sensu Bentham. This group is distinguished by having leaves simple and entire, the torus straight or slightly oblique, the inner perianth surface hairy, the ovary densely hairy and either sessile or shortly stipitate (the ovary glabrous only in a few species and then the stipe hairy), the pollen-presenter lateral to very oblique. McGillivray (1993: 453) placed these species in his Group 2 (Group 2.1.1.1.1), a very large group united by having seeds with an apical elaiosome and a subapical pulvinus, outer face convex, revolute at the margin, and with a fine downy covering of hair-like processes. The species in this group have the perianth hairy on both surfaces, the ovary densely hairy, sessile or almost so, the torus straight or almost so, the style clearly longer than the perianth.

Bentham (1870: 443) reduced G. canescens in rank to variety, as G. arenaria var. canescens (R. Br.) Benth. McGillivray (1986: 1) recognised two subspecies of G. arenaria, subsp. arenaria and subsp. montana, the latter combination formed by reducing the status of G. montana. McGillivray (1993: 405) has also referred var. canescens to synonymy under $G$. arenaria subsp. arenaria, a subspecies in which a considerable degree of population-based diversity is accommodated. Significant shared features influencing his taxonomy were the shape of the flowers, particularly the acumination of the limb; the structure of the nectary ... and the presence of hairs on the nectary'(McGillivray 1993: 267). 
Our studies show that, notwithstanding the features uniting the populations, the concepts employed by McGillivray are too broad and give insufficient emphasis to other characters, particularly the distribution and orientation of trichomes on the inner perianth surface, length of the tepal-limb appendage, and orientation of floral buds, fruit and the style in fruit, that delimit the phenotypes more precisely. Further, several phenotypes do not have hairs on the nectary and, in many of those that do, the hairs are closely associated with the ovary which is usually adnate to the nectary. This character may be less diagnostic than previously thought.

The present study showed that it was appropriate to circumscribe G. arenaria more narrowly, and to recognise two subspecies, subsp. arenaria and subsp. canescens (R. Br.) P. Olde \& N. Marriott. Subsp. canescens is entirely congruent with G. arenaria var. canescens. We have re-ranked this variety as a subspecies in order to conform with infraspecific rankings generally employed in the genus.

All populations here treated as G. arenaria have a dense, spreading indumentum of short, simple hairs on the inner perianth surface above the beard. The beard itself, present in all populations of G. arenaria sensu McGillivray, consists of reflexed, simple hairs condensed in a band, usually just above and overlapping the glabrous, concave base of the inner perianth surface. The diagnostic spreading indumentum is distributed immediately above the beard almost to the curve and is most dense on the ventral tepals although it is sometimes found on the dorsal tepals as well. Scattered, appressed hairs occur elsewhere on the inner perianth in the vicinity of the curve and on the dorsal tepals. Populations which either lack an indumentum above the beard or have a sparse appressed indumentum in its place are here excluded from G. arenaria. In all species (including G. arenaria sensu stricto), appressed hairs on the inner perianth surface are biramous. The occurrence of this hair-type on the inner perianth surface has otherwise been observed in only two species, G. asparagoides and G. batrachioides (McGillivray 1993: 5).

Maintenance of G. montana by Makinson (1991) at specific rank is supported here. Four new species (three from the Grafton area of New South Wales and one from south-eastern Queensland and north-eastern New South Wales) are separated from G. arenaria subsp. arenaria sensu McGillivray: G. banyabba P. Olde \& N. Marriott, G. masonii P. Olde \& N. Marriott, G. quadricauda P. Olde \& N. Marriott and G. rhizomatosa $P$. Olde \& N. Marriott. However, even after the separation of these species and the recognition of two subspecies in G. arenaria, variation between populations of both subspecies of $G$. arenaria warrants further study and it is likely that more taxa will be recognised.

McGillivray (1986: 11) recognised two new subspecies in G. obtusiflora (subsp. kedumbensis and subsp. granulifera). Our study showed that, apart from features observed by McGillivray, these currently recognised subspecies are morphologically distinct from each other on many characters and occur in several, geographically disjunct, self-reproducing populations. Furthermore, they are morphologically as close to other phenetically similar species as they are to G. obtusiflora s. str. We therefore consider that they each warrant recognition as distinct species. Accordingly, the combinations G. granulifera (McGillivray) P. Olde \& N. Marriott and G. kedumbensis (McGillivray) P. Olde \& N. Marriott are formally made. Two homogeneous populations included in G. obtusiflora subsp. granulifera by McGillivray are also recognised as distinct and are here described as G. guthrieana P. Olde \& N. Marriott.

The results are presented after extensive field work and study of wild populations, plants in horticulture and dried specimens at BRI, MEL and NSW. Species concepts as outlined in a previous paper (Olde \& Marriott 1993b) are applied and result in the acceptance by us of more taxa at specific rank than by McGillivray (McGillivray 1986, 1993). 
Conservation codes follow Briggs and Leigh (1988: 7-13). Species descriptions and terminology follow McGillivray (1993) and Olde \& Marriott (1993a, 1993b).

\section{Morphology}

The perianth limb is defined as the more or less globose structure at the apex of the bud; it is made up of the coherent apical, cup-like portions of the tepals (McGillivray 1993: 4). The perianth limb consists of four segments, here termed the limb-segments (following McGillivray 1993) or tepal-limbs. In most species the tepal-limbs separate at anthesis. Except in species in which the segments remain coherent after anthesis, the perianth limb ceases to exist as a discrete organ and its features are thereafter determinable only by reconstruction. In some species, the tepal lamina lengthens beyond the anther-bearing cup visible on the inner surface of each tepal-limb and forms an appendage. In these cases, the tepal-limb or limb-segment includes the appendage. The appendage is measured on the inner face from the apex of the anther-bearing cup to the end of the lamina.

\section{Key to species most closely related to $G$. arenaria}

1 Most floral bracts $>2 \mathrm{~mm}$ wide; young conflorescences conspicuously imbricate G. polybractea

1* Most floral bracts $<2 \mathrm{~mm}$ wide; young conflorescences not conspicuously imbricate 2 Nectary linguiform (extending horizontally $1-3 \mathrm{~mm}$ beyond the torus)

2* Nectary not linguiform; nectary not extending horizontally

G. alpina

3 Apex of bud acute to acuminate or caudate

4 Inner perianth surface with a sparse appressed indumentum above the beard on the ventral tepals or indumentum lacking above the beard

5 Leaf undersurface with a dense matted indumentum

G. rhizomatosa

$5^{*}$ Leaf undersurface either sericeous or sparsely hairy

6 Beard positioned about half-way between the base and the curve on the inner perianth surface

G. masonii

$6^{*}$ Beard positioned sub-basally or in the basal third of the inner perianth surface

7 Leaf lamina not visible on the undersurface through a sericeous indumentum; style villous

G. montana

$7^{*}$ Leaf lamina clearly visible on the undersurface through the indumentum; style pubescent

8 Leaves $<2 \mathrm{~cm}$ long with obtuse apex; fruits horizontal to the pedicels with style infracted at the base; conflorescence 2-4-flowered

G. quadricauda

$8^{*}$ Leaves $>2 \mathrm{~cm}$ long with acute apex; fruits erect with erect style; conflorescences $>6$-flowered

G. banyabba 
$4^{*}$ Inner perianth surface with a dense, spreading indumentum above the beard, mostly on the ventral tepals $G$. arenaria

$3^{*}$ Apex of bud rounded, depressed or emarginate

9 Perianth below the curve subglobose; beard positioned near the curve in the upper half of the inner perianth; longest floralrachis usually $>15 \mathrm{~mm}$ long

G. floribunda

9* Perianth oblong below the curve with basal dilation; beard positioned in the lower half of the inner perianth or over much of the inner surface below the curve; longest floral rachis $<15 \mathrm{~mm}$ long

10 Most leaves with mucro 1-2 mm long; style of fruits strongly inflexed; tepal-limb segments very prominently carinate

G. mucronulata

$10^{*}$ Most leaves with mucro $<1 \mathrm{~mm}$ long; style of fruits erect; tepal-limb segments carinate or faintly ribbed

11 Stylar indumentum consisting of hairs with coloured contents (rarely white); nectary oblong with a clearly defined margin; tepal-limb segments sometimes with prominent horn-like protuberance

G. chrysophaea

$11^{*}$ Stylar indumentum white; nectary cushion-like to reniform, lacking a clearly defined margin; tepal-limb segments lacking a prominent horn-like protuberance

12 Pollen-presenter $<2 \mathrm{~mm}$ long, round to obovate-elliptic

13 Pollen-presenter noticeably convex with inconspicuous stigma; pistils 18-23 mm long; perianth red with cream limb, persistent; habit root-suckering

G. obtusiflora

$13^{*}$ Pollen-presenter flat (rarely convex)with prominent stigma; pistils 12.5-18 mm long; perianth green to cream, deciduous; habit lignotuberous

G. kedumbensis

$12 *$ Pollen-presenter $>2 \mathrm{~mm}$ long, obovate, elliptic or oblong, usually with a short basal attenuation.

14 Leaf undersurface sericeous, upper surface finely granulose; peduncles either absent or present and densely hairy; pistil 21$24 \mathrm{~mm}$ long; fruits $<15 \mathrm{~mm}$ long

G. granulifera

$14^{*}$ Leaf undersurface villous or loosely so, upper surface coarsely granular; peduncles glabrous or sparsely hairy; pistil 25-26 mm long; fruits c. $20 \mathrm{~mm}$ long

G. guthrieana

1. Grevillea arenaria $R . B r$.

(Brown 1810: 172)

TYPE CITATION: 'In Novae Hollandiae ora orientali; prope Port Jackson; ad ripas arenosas fluviorum.'

LECTOTYPE (McGillivray 1993: 405): Low sandy Island of the Nepean, a little above its junction with the Grose 1803-4. R. Brown (Bennett 3325)['R.B.'] BM - whole sheet (photo seen). Isolecto: E (n.v.), K (photo seen), G (n.v.), MEL 46996 (n.v.), NSW 92786, NY ex E (n.v.).Note on Typification: Vallance (1990: 69) indicates that Brown and 
party visited the site of the type collection on 23 June 1802 and again in OctoberNovember 1803. However, Burbidge (1955: 300) indicates that the lectotype was collected by Caley (in September). A collection by Caley (Caley NSW 131528), dated September 1807, agrees well with the Lectotype except that it is in an more advanced stage of flowering. The possibility that Brown incorporated the Caley collection without acknowledgement cannot be excluded. The number 3325 associated with the lectotype was given by J.J. Bennett, Brown's successor as Keeper of the Botanical Department at the British Museum.

?Lysanthe cana Knight, Cult. Proteeae: 117 (1809).

TYPE CITATION: 'Introduced at Clapham before I went there, and supposed to be a Sophora, till it flowered in 1804.'

TYPE: Not known. R. Brown (1810), who presumably saw this taxon, referred it to synonymy under Grevillea arenaria. In the absence of a type, McGillivray (1993) treated this as a name of uncertain application. However, a change of name for G. arenaria remains a possibility and conservation of the name $G$. arenaria is recommended.

G. ferruginea Sieber ex Spreng., Syst. Veg., 4, Cur. Post.: 46 (Jan-Apr. 1827); G. ferruginea Sieber ex Schultes et Schultes f., Syst. Veg. Mant. 3: 280 (Jul-Dec. 1827) nomen illeg.

Type citation (McGillivray 1993): 'Sieber Fl. Nov. Holl. No. 27 (B, BM, G, G-DC, K, LE, NSW, NY, P, TCD)'. No types seen. The isotype at NSW could not be found.

\section{Key to subspecies of $G$. arenaria}

1 Leaf undersurface sericeous, tomentose, villous or loosely so; pistils $22-27 \mathrm{~mm}$ long subsp. arenaria

$1^{*}$ Leaf undersurface velutinous; pistils $26-32 \mathrm{~mm}$ long subsp. canescens

\section{Subsp. arenaria}

A single-stemmed shrub $2-4 \mathrm{~m}$ high; branchlets rounded to slightly angular, villous, tomentose, sericeous or velutinous. Leaves $1-7.5 \mathrm{~cm}$ long, $0.3-1.5 \mathrm{~cm}$ wide, ascending, simple, shortly petiolate, oblong-elliptic to obovate, rarely linear; apex obtusemucronate to acute, the mucro $0.5-1 \mathrm{~mm}$ long; upper surface convex, velvety to sparsely pubescent or silky, sometimes glabrous and finely to coarsely scabrous, usually with inconspicuously raised venation, longitudinally wrinkled when dried, sometimes the venation obscure; margin entire, shortly recurved to loosely revolute; lower surface loosely villous, silky or felted-tomentose, velutinous, sometimes with a matted indumentum overlain by longer, loose hairs, the midvein usually evident, sometimes obscured; texture firmly chartaceous to thin and pliable. Conflorescence erect to decurved, sessile to pedunculate, usually terminal on short branchlets, sometimes axillary, simple or few-branched; unit conflorescence $1-2.5 \mathrm{~cm}$ long, open, fewflowered (4-10), secund to subcylindrical with development basipetal; peduncles 0$5(-15) \mathrm{mm}$ long, sometimes quite slender, erect to decurved, sometimes sharply deflexed at the base; floral rachises $0.2-2.5 \mathrm{~cm}$ long; peduncles and floral rachises tomentose to pubescent; floral bracts $1-2.5 \mathrm{~mm}$ long, ovate to narrow-triangular, pubescent, usually caducous, sometimes persistent at anthesis. Flowers in bud spreading to patent, ultimately acroscopic or abaxially so on retrorse pedicels: pedicels $2-8 \mathrm{~mm}$ long, tomentose-pubescent to villous or velutinous, patent to retrorse; torus $1.5-2.5 \mathrm{~mm}$ 
across, oblique, undulate; nectary $3 / 4$ annular, collar-like with an undulate and sometimes recurved margin, sometimes with inconspicuous hairs on the upper surface; perianth 6-15 mm long, 3-5 mm wide, erect in late bud, oblong or curved-oblong below the curve with a slight basal dilation, the outside tomentose-pubescent with crisped hairs, the inside white-bearded above the level of the ovary with straight reflexed hairs condensed in a band above the glabrous, concavitous base, also a dense band of spreading hairs developed mostly on the ventral tepals, but sometimes also on the dorsal tepals, extending between the top of the beard to just below the curve, usually a patch of reflexed hairs also just below the anther-bearing cavity; tepals medially ribbed, cohering except along the dorsal suture before anthesis; limb ovoid or ovoid-acuminate, the tepal-limbs strongly to faintly ribbed, bearing an acute to acuminate-caudate terminal appendage $0.3-5 \mathrm{~mm}$ long, revolute at anthesis, the dorsal tepal-limbs sometimes markedly reflexed laterally after anthesis; pistil $22-27 \mathrm{~mm}$ long; ovary sessile, densely villous; style at first exserted at the curve on the dorsal side and looped upwards, straight to slightly incurved after anthesis, pubescent to subvillous, sparsely hairy to glabrous on the ventral surface especially near the enlarged, flattened style-end; style-end slightly exposed before anthesis; pollen-presenter 2-4 mm long, 2-3 mm wide, lateral, obovate, usually flat, umbonate, sometimes with a short, basal appendage. Fruit 12-22 $\mathrm{mm}$ long, 6-8.5 mm wide, often persistent, erect on the pedicels, oblong/ellipsoidal with prominently raised longitudinal ridges and attenuated apex, sparsely tomentose; style persistent, erect to slightly incurved; pericarp c. $0.5 \mathrm{~mm}$ thick. Seed 10-12 $\mathrm{mm}$ long, $3.5 \mathrm{~mm}$ wide, ellipsoidal with subapical, cushion-like swelling and strongly revolute margins, the anterior margin bordered by a narrow, waxy wing drawn into a folded, apical elaiosome 1-2 mm long excurrent from the testa; outer face wrinkled, pubescent; inner face obscured.

FLower COLOUR: Perianth green to yellow, pink on the limb; style green.

FLowerInG PERIOD: Late winter to early summer.

Distribution: New South Wales: Central Coast, South Coast, Southern Tablelands: from the Richmond-Yarramundi area in the north to Deua National Park in the south. Its occurrence at Curricabark, cited by McGillivray (McGillivray 1993: 268), is not substantiated and results from confusion with G. granulifera (syn. G. obtusiflora subsp. granulifera) which was once thought to be a form of G. arenaria.

\section{CONSERVATION STATUS: Not rare.}

HABITAT \& ECOLOGY: Grows in a variety of habitats, usually riverine or on hills overlooking creeks and rivers in brown, sandy loam, granitic loam, sometimes on limestone hills or in association with rhyolite.

VARIATION: Within subsp. arenaria there are several elements, loosely divided here into two forms. Population distribution, variation between populations and analysis of character-states examined indicated to us that these elements are insufficiently discontinuous to warrant formal separation on present information.

The first form, here termed the villous form, consists of plants with loosely villous branchlets and leaf undersurface, leaf margins loosely revolute, perianth limb recurved in the apical half with caudate to acuminate tepal-limb appendages ranging from $1.2-5 \mathrm{~mm}$ long, and pedicels usually $5-8 \mathrm{~mm}$ long. Although the type of G. ferruginea Sieber ex Schultes et Schultes $\mathrm{f}$. has not been seen, Meisner's description (Meisner 1856: 359) suggests that it may belong with this form. The possibility that this species should be reinstated is not excluded but more study using different characters is required. It should be noted, however, that the foliar hairs are not ferruginous. Collections from the Bent's Basin, Colo Vale, Hilltop, MaIdon, Douglas Park, Mittagong area have sessile, few-flowered conflorescences, perianths very 
sparsely hairy and up to $15 \mathrm{~mm}$ long with tepal-limb appendages $3-5 \mathrm{~mm}$ long whereas those from Joadja, Yerranderie, central Coxs River, Wingello, Nowra, Moruya, Lake Conjola, Mogo have pedunculate conflorescences, sometimes with the peduncles deflexed at the base; tepal-limb appendages vary from 1.2-4 mm long; perianths are more strongly revolute and range from 6-10 $\mathrm{mm}$ long with a moderately dense indumentum. Plants from the Mt Werong area, here included in subsp. canescens, closely approach this form.

The second form, here termed the silky form, consists of plants with a 'close' foliar indumenturn, either sericeous or felted-tomentose on the branchlets and leaf undersurface, leaf margins shortly recurved, conflorescences on peduncles deflexed at the base, flowers with a strongly recurved perianth and blunt limb (tepal-limb appendage $0.5-1.5 \mathrm{~mm}$ long), and short pedicels (mostly 2-5 $\mathrm{mm}$ long). These collections are mostly (but not exclusively) from plants which occur on limestone in the Bungonia, Goulburn, Wombeyan Caves, Endrick River, Braidwood, Deua area. They are morphologically similar to subsp. canescens and to some elements of the plants of the villous form but differ in the indumentum of the leaf undersurface.

Discussion: The lectotype of G. arenaria s. str. has an open, appressed, subsericeous indumentum on the leaf undersurface, strongly decurved, pedunculate conflorescences and perianth with an acute limb (appendage c. $1.5 \mathrm{~mm}$ long), character-states mostly concordant with the silky form. However, the distribution of this collection is anomalous in that it was collected growing in river sand on the Nepean River system at the north-eastern limit of the species' range. Apart from recent collections at Shaws Creek, Yarramundi (Olde 93/10-19), there have been no collections from the type locality since the Brown/Caley collections. The Yarramundi plants, some of which are hybridised with G. mucronulata, do not appear to be a natural population, though they may have been introduced in soil used in road building, possibly from nearby Richmond. They occur in a small population of less than 20 plants in a disturbed roadside situation and are not found in surrounding natural vegetation. They have an extremely short $(0-0.5 \mathrm{~mm}$ long) tepal-limb appendage. The possiblity that the lectotype is of hybrid origin or forms part of a third race within G. arenaria is not excluded but we were unable to separate it satisfactorily from the silky form.

A morphological similarity to the silky form is exhibited in collections from the Yalwal area (here placed in the villous form because of their leaf indumentum) which have tepal-limb appendages c. $1 \mathrm{~mm}$ long (e.g. Ellison NSW 117304). These anomalies of distribution and morphology indicate that further formal nomenclature is not appropriate in the separation of the forms at this stage.

The major distinguishing features of G. arenaria s. str. are:- leaves simple and entire, oblong-obovate to oblong-elliptic with short mucro; perianth limb acute to acuminate-caudate; inner perianth surface bearded and with a dense, zone of spreading hairs on the ventral tepals above the beard; nectary usually with hairs on the upper surface; ovary sessile, villous; style green, tomentose to pubescent or with a rather untidy, irregular indumentum; pollen-presenter lateral, obovate; fruits erect, prominently ribbed; fructual style persistent, erect to slightly incurved.

Selected Specimens (108 examined): New South Wales: Silky form: Central Coast: Ikens [?Aikens] sand flat, near junction of the Grose and Hawkesbury Rivers, Caley, Sep 1807 (NSW 131528); Shaws Creek, Yarramundi, Olde 93/14, 14 Aug 1993. Southern Tablelands: Endrick River near Nerriga, Craven 643, 13 Oct 1965 (NSW, BRI); $20 \mathrm{~km} \mathrm{~W}$ of Braidwood, Stewart $22 \mathcal{E}$ Windsor, 13 Aug 1984 (NSW); Bungonia Lookdown, Rodd 3636, 19 Mar 1981 (NSW); Goulburn, C.W.E. Moore 2621, 18 Sep 1953 (NSW, CANB); Everywhere on Shoalhaven River, Moore, Feb 1865 (NSW); $18 \mathrm{~km}$ NE of Taralga, Wombeyan Caves, Tyrrell 99 \& Streiman, 18 Oct 1978 (NSW); Barbers Creek (near Tallong), Maiden, Oct 1892 (NSW 26356). South Coast: Deua National Park, cliff NW of Mongamula Mt, Gilmour 4730, 26 May 1984 (NSW). 
Villous form: Central Coast: Bents Basin, near Wallacia, Olde 93/26, 19 Aug 1993; Colo Vale, Cheel, Feb 1911 (NSW 92798); Bonnum Pic Creek, $8 \mathrm{mi} \mathrm{SE}$ of Yerranderie, Constable 5667, 22 Jan 1965 (NSW); Cedar Creek, Coxs River, Whaite, 1 Dec 1948 (NSW); Hilltop, Cheel, Sep 1920 (NSW); Mt Jellore, Cheel, 27 Apr 1912 (NSW 92800). South Coast: Wingello, D' Aubert 770, 12 Jul 1990 (NSW); Yalwal, W of Nowra, Ellison, Nov 1974 (NSW 117304); Moruya, Baeuerlen, Jun 1890 (NSW); Myrtle Creek, between Conjola and Milton, Rodway 7637, 5 Feb 1939 (NSW); Mogo, Adams 3232, 14 Jun 1973 (NSW).

Grevillea arenaria subsp. canescens $(R . B r$.) P. Olde $\mathcal{E} N$. Marriott, comb. et stat. nov.

BAsIonyM: G. canescens R. Br., Prodr. Suppl. Prot. Nov.: 18 (1830).

Grevillea arenaria var. canescens (R. Br.) Benth. (Bentham 1870: 443).

LECTOTYPE (McGillivray 1993: 405): Grevillea cinerea Cunningh in Field Mem. N.S. Wales (BM - specimen at the left of the sheet) (photo seen). Isolecto: B (n.v.), G-DC (n.v.).

A single-stemmed shrub to $1.5-3 \mathrm{~m}$ tall, sometimes a root-suckering shrub $0.3-1 \mathrm{~m}$ high; branchlets velutinous. Leaves $1-4.5 \mathrm{~cm}$ long, $0.4-1 \mathrm{~cm}$ wide, oblong to elliptic or obovate, the apex obtuse-mucronate, margin shortly recurved; upper surface pubescent, lower surface velutinous, the midvein usually obscure, sometimes prominent. Conflorescence decurved, pedunculate, terminal, usually simple, subcylindrical; peduncles and floral rachises pubescent to velutinous; floral bracts $1.2-3 \mathrm{~mm}$ long, 1 $\mathrm{mm}$ wide, triangular, velutinous, caducous. Flowers: pedicels $3-5 \mathrm{~mm}$ long, velutinous; perianth 6-10 mm long, strongly revolute, velutinous on the outside, the limb with appendages $0.2-3 \mathrm{~mm}$ long; pistils $26-32 \mathrm{~mm}$ long; style pubescent; pollenpresenter 3-4 mm long. Otherwise as for subsp. arenaria.

FLOWER Colour: Perianth green, yellow or red at the base with a pink to red limb; style green.

FLOWERING PERIOD: Spring.

Distribution: New South Wales, where recorded from the Central Tablelands, Southern Tablelands, Central Western Slopes.

CONSERVATION Status: Not rare.

HABitat \& ECOLOGY: Grows in deep yellow sand, granitic sand, brown gravelly loam or basalt-derived soils, usually in dry, sclerophyll forest. We have observed nectarivorous birds probing the flowers on plants growing at The Rocks, near Bathurst.

VARIATION: Subsp. canescens is readily distinguished from other populations of $G$. arenaria by the velutinous indumentum of its leaf undersurface. However, there is a degree of floral diversity within the subspecies approaching that accommodated in subsp. arenaria. Plants from the Gilgandra district are low, root-suckering plants c. 50 $\mathrm{cm}$ high with an entirely red perianth. From our observations, they do not appear to set fruit and while they may be reproductively isolated, they are insufficiently discontinuous morphologically to warrant formal separation at this stage. Plants from the Eumungerie, Dubbo and Bathurst area are robust, single-stemmed shrubs and have flowers with either a yellow or reddish perianth that have strongly reflexed dorsal tepal-limbs after anthesis and set abundant fruits. While all these collections have tepal-limb appendages $0.5-3 \mathrm{~mm}$ long, collections from the Tumut-Kiandra area have a very obscure appendage $0.2-0.5 \mathrm{~mm}$ long.

Selected SPECimens (48 examined): New South Wales: Central Tablelands: Coxs River, Cunningham 50, 1822 (NSW); Winburndale Nature Reserve (20 km E of Bathurst), Coveny 9631, 2 Oct 1977 (NSW, B, CBG, K, PER, RSA); Blackheath, near Kanimbla, Burgess, 28 Sep 1962 (NSW); Galong Creek, Megalong Valley, Chadwick, 6 Aug 1951 (NSW); Rydal to Mt Victoria, Boorman, Dec 1900 (NSW); Ruby Creek Falls, near Mt Werong, Makinson 102, Coveny \& Bishop, 18 Sep 
1985 (NSW); Never Never, 24 miles [38.4 km] E of Rylstone, Baker, Oct 1897 (NSW); Jenolan Caves, Blakely, July 1899 (NSW). Southern Tablelands: Upper Tumut River, SW of Yarrangobilly, Trainor, Sep 1911 (NSW); Yarrangobilly Caves, Betche, Feb 1897 (NSW); Kiandra, Forsyth, Dec 1901 (NSW). Central Western Slopes: Goonoo (Goonoo) Forest, NE of Dubbo, Chapman 1244 \& 1245, 6 Oct 1974 (NSW); Gilgandra Flora Reserve, Coveny 2354, 10 Oct 1969 (NSW).

\section{Grevillea banyabba $P$. Olde $\mathcal{E} N$. Marriott, sp. nov.}

A Grevillea arenaria alabastris ad axem parallelis, perianthio intus super barbam sparse sericeo, nectario glabro, tenui, arcuato, ovario plerumque brevissime stipitato, pedunculis longioribus erectisque, foliis infra sparse sericeis distinguitur.

Holotype: New South Wales: North Coast: Fortis Creek, $3.5 \mathrm{~km}$ along track from Coaldale-Grafton Rd, P. Olde 92/100 \& D. Mason, 21 Sep 1992 (NSW). Isotypes: BRI, CANB, MEL.

Open, few-branched shrub 1-1.5 m high; branchlets slender, rounded, loosely villous. Leaves $2.5-3.8 \mathrm{~cm}$ long, $0.5-1 \mathrm{~cm}$ wide, narrowly obovate to oblong-elliptic, shortly petiolate, simple, the apex usually acute, occasionally obtuse-mucronate, the mucro c. $0.5 \mathrm{~mm}$ long; upper surface coarsely granular to scabrous, glabrous or with a few scattered, appressed hairs, the midvein, lateral veins and reticulum slightly raised; margin entire, shortly recurved to almost flat; lower surface openly sericeous with prominently raised midvein; texture papery. Conflorescence erect, terminal or axillary, pedunculate to subsessile, simple or few-branched; unit conflorescence loose, subsecund, 6-14-flowered with development basipetal; peduncles (0-)10-25 mm long, loosely brown-villous; floral rachis $10-25 \mathrm{~mm}$ long, loosely brown-villous; floral bracts 2-2.5 mm long, $0.4 \mathrm{~mm}$ wide, narrow-triangular with attenuate apex, loosely brownvillous outside, usually persistent to anthesis. Flowers in bud aligned parallel to the rachis, ultimately acroscopic; pedicels $7.5-10 \mathrm{~mm}$ long, loosely brown-villous; torus $1.5-1.8 \mathrm{~mm}$ across, oblique c. $40^{\circ}$; nectary glabrous, arcuate, thin, rising $0.2-0.5 \mathrm{~mm}$ above the toral rim, the margin smooth to undulate; perianth $12 \mathrm{~mm}$ long, $4.5 \mathrm{~mm}$ wide, erect till late bud, oblong with slight basal dilation, sparsely sericeous to loosely villous outside, the tepals with a prominent midrib, detaching soon after anthesis, bearded inside c. $3 \mathrm{~mm}$ from the base, the hairs reflexed and extending over a basal glabrous cavity, sparsely sericeous above the beard to the limb; limb $3 \mathrm{~mm}$ long, 3 $\mathrm{mm}$ wide, revolute at anthesis, angularly ovoid-acuminate, loosely tomentose, the segments prominently ribbed to the apex, the apex drawn into an appendage $0.7-1.5$ $\mathrm{mm}$ long; pistil $25-27 \mathrm{~mm}$ long; stipe c. $0.3 \mathrm{~mm}$ long, villous; ovary $2.5 \mathrm{~mm}$ long, 2.5 $\mathrm{mm}$ wide, subsessile, white-villous, the longest hairs c. $3 \mathrm{~mm}$ long; style straight to slightly incurved, openly tomentose in the proximal third, bearing a mixed indumentum of short, erect trichomes c. $0.05 \mathrm{~mm}$ long and longer biramous trichomes in the distal two-thirds, the indumentum extending onto the style-end; pollen-presenter 2 $2.5 \mathrm{~m}$ long, $1.5 \mathrm{~mm}$ wide, lateral, obovate, \pm flat; stigma distally off-centre. Fruits (M. Hodge s.n. cult.) 15-21 mm long, $7 \mathrm{~mm}$ wide, erect, oblong-ellipsoidal, dorsally ribbed, sparsely villous; style persistent, erect; pericarp $0.3-0.5 \mathrm{~mm}$ thick. Seeds $13 \mathrm{~mm}$ long, $2.5 \mathrm{~mm}$ wide, narrow-oblong with subapical and subbasal pulvinus; outer face smooth, shiny with scattered, fine hairs; inner face flat to slightly concave; margins revolute, a narrow, waxy wing along one side drawn into an excurrent, slightly oblique, apical elaiosome. Figure 1.

EPITHET: Taken from the Banyabba Nature Reserve wherein the holotype was collected. The epithet is used as a noun in apposition, no' a declinable adjective.

FLOWER COLOUR: Perianth all red except the basal dilation green ageing yellow. Style green.

Flowering Period: August-October.

Distribution: New South Wales, North Coast in the Fortis Creek-Coaldale area where it is confined mostly to the Banyabba Nature Reserve. 
Conservation Status: Suggested 2 EC.

HABITAT AND ECOLOGY: Grows in well-drained sandy soil in open, eucalypt forest, near or at the top of ridges.

Discussion: G. banyabba differs from G. arenaria in the parallel alignment of its buds with the floral rachis, the sparse, appressed indumentum of the inner perianth surface above the beard, its glabrous, more conspicuous, thin-walled nectary, its very shortly stipitate ovary, its longer, erect peduncles, its leaves sparsely silky on the undersurface. G. masonii differs in its shorter, more conspicuously dilated perianth with the beard positioned about the middle on the inner perianth, shorter pistils, pedicels and peduncles, smaller ovary, round to elliptic pollen-presenter, leaves usually shorter $(<2.5 \mathrm{~cm})$ and mostly obovate to elliptic and with rounded apex, the shape and prominence of the nectary, and in its very oblique fruits with infracted style.

VARIATION: Perianth indumentum varies in density but the species is otherwise relatively uniform.

SPeCimens eXamined: New South WAles: North Coast: Copmanhurst, Mason, 5 Sep 1992 (NSW); Banyabba Nature Reserve, Mason s.n., Sep 1992 (NSW); Rocky Creek Nature Reserve, E side of Grafton-Coaldale Rd, Lander 275, 23 Aug 1973 (NSW); Fortis Creek, Coaldale, Grieves, 29 Sep 1968 (NSW).

\section{Grevillea masonii P. Olde $\mathcal{E} N$. Marriott, sp. nov.}

A Grevillea arenaria perianthio saccato intus in medio barbato super barbam sparse sericeo, nectario glabro, foliis plerumque brevioribus infra sparse sericeis, fructibus ad pedicellos horizontalibus stylo ad basin infracto distinguitur.

Holotype: New South Wales: North Coast: Casino-Lawrence Road, $7.4 \mathrm{~km}$ from Casino-Grafton Highway, P. Olde 92/99 \& D. Mason, 21 Sep 1992 (NSW). Isotypes: BRI, CANB.

Lignotuberous shrub $0.3-0.5 \mathrm{~m}$ high with numerous, short branches; branchlets slender, rounded, tomentose. Leaves $0.5-2.5(-3) \mathrm{cm}$ long, $0.2-1.1 \mathrm{~cm}$ wide, narrowly obovate to

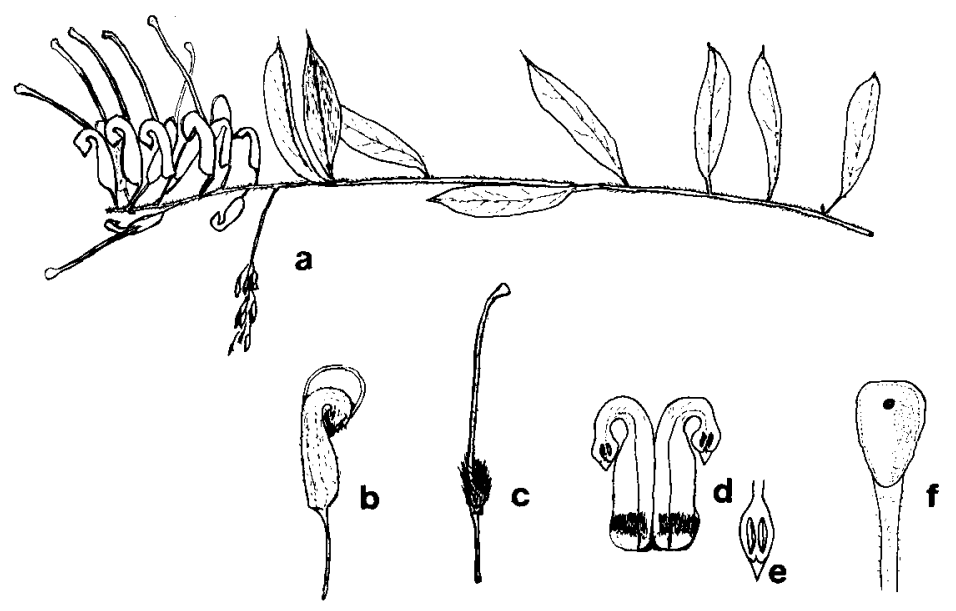

Figure 1. G. banyabba. a. Habit (x 0.5); b. Perianth before anthesis (x1); c. Pistil (x1); d. Inner perianth (x1); e. Tepal-limb showing appendage (x2.5); f. Pollen-presenter (x3.5). 
elliptic, shortly petiolate, simple, the apex obtuse-mucronate with mucro $0.2-0.5 \mathrm{~m}$ long; upper surface smooth to finely granular, glabrous or with a few scattered, appressed hairs, the midvein, lateral veins and reticulum slightly raised; margin entire, shortly recurved to almost flat; lower surface openly sericeous, the midvein prominently raised in the proximal half, obscure in the distal half; texture papery. Conflorescence erect, terminal or axillary, shortly pedunculate to subsessile, simple to few-branched; unit conflorescence umbel-like, 6-10-flowered with development basipetal; peduncles 1-5 $\mathrm{mm}$ long, tomentose; floral rachis 1-5 $\mathrm{mm}$ long, tomentose; floral bracts $1-1.5 \mathrm{~mm}$ long, $0.2-0.5 \mathrm{~mm}$ wide, narrow-triangular with attenuate apex, brown-tomentose outside, closely appressed to the rachis between the pedicels, usually persistent to anthesis. Flowers adaxially acroscopic; pedicels $4-8 \mathrm{~mm}$ long, loosely tomentose; torus $1.5-1.8 \mathrm{~mm}$ across, oblique c. $30^{\circ}$; nectary glabrous, arcuate, the margin undulate; perianth 9-11 $\mathrm{mm}$ long, 4.5-5.5 $\mathrm{mm}$ wide, ovoid-saccate with a prominent basal dilation, openly tomentose outside, the tepals with a prominent midrib, detaching soon after anthesis, bearded inside c. $4 \mathrm{~mm}$ from the base just below the curve, the hairs simple, reflexed and extending over the basal glabrous cavity, with scattered appressed trichomes above the beard to the limb; limb $3 \mathrm{~mm}$ long, $3 \mathrm{~mm}$ wide, ovoid, loosely tomentose, the segments prominently ribbed to the apex, the apex drawn into a short appendage $0.2-0.8 \mathrm{~mm}$ long; pistil 18-24 $\mathrm{mm}$ long; ovary $2 \mathrm{~mm}$ long, $2 \mathrm{~mm}$ wide, sessile, villous, the longest hairs c. $2 \mathrm{~mm}$ long; style straight to slightly inflected just above the ovary, tomentose in the proximal third, sparsely tomentose and with a mixed indumentum of short, erect trichomes c. 0.05 $\mathrm{mm}$ long in the distal two-thirds, the indumentum sometimes extending onto the style-end; pollen-presenter $2 \mathrm{~mm}$ long, $1-1.5 \mathrm{~mm}$ wide, lateral, round to elliptic, \pm flat with a crenulate margin; stigma slightly distally off-centre. Fruit 11-18 mm long, 5$6 \mathrm{~mm}$ wide, very oblique to horizontal to the pedicel with the suture directed outwards, ovoid to oblong-ellipsoid, costate, sometimes faintly so, sparsely tomentosepubescent to loosely villous; style persistent, strongly inflected at the base; pericarp $0.5 \mathrm{~mm}$ thick. Seed $8 \mathrm{~mm}$ long, $2.5 \mathrm{~mm}$ wide, ellipsoidal to narrowly obovoidal with a subapical cushion-like swelling and with strongly revolute margins, a narrow, waxy border along the anterior margin extending into an apical elaiosome c. $1 \mathrm{~mm}$ long excurrent from the testa; outer face convex, smooth, sparsely pubescent; inner face flat. Figure 2.

EPITHET: Honours David Mason (1944- ) of Coraki, near Lismore, New South Wales. The Mason family, including Reginald (1912- ), formerly of South Australia, have been keen amateur collectors and enthusiasts of the Australian flora, especially Grevillea and Eremophila. David Mason was especially helpful in locating and collecting specimens of Grevillea in the Grafton-Lismore area.

FLOWER COLOUR: Perianth green at the base, red on the limb; style green.

FLOWERING PERIOD: Late winter-spring.

Distribution: New South Wales; North Coast. Confined to a few localities near Grafton.

CONSERVATION STATUS: 2E suggested. All known populations occur on degraded road verges or on private land subject to grazing or cultivation.

HABITAT AND ECOLOGY: Confined to degraded verges and pastureland of formerly open eucalypt woodland at low elevations. Gravelly loam soils.

Discussion: The lignotuberous, low-growing habit, saccate perianth with beard positioned about the middle on the inner surface, oblique to transverse orientation of fruit to the pedicels with style infracted at the base are very clearly diagnostic characters for G. masonii. G. arenaria differs in the dense spreading indumentum of the inner perianth above the beard, the hairy nectary (sometimes), the usually densely 
hairy leaf undersurface and the erect fruits with erect style. G. masonii is most closely related to G. quadricauda which differs in its single-stemmed, bushy habit, its fewflowered conflorescences (2-4), its oblong perianth with slight basal dilation with the beard positioned sub-basally, longer tepal-limb appendage $(1.5-2 \mathrm{~mm}$ ) and slightly longer pistils (25-27 mm).

VARIATION: A relatively uniform species.

Selected specimens (5 examined): New South Wales: North Coast: Mill Creek, property of Keith Delaforce, Casino-Grafton Rd, D. Mason, August 1992 (NSW); between Lawrence and Casino, Forsyth, Sep 1900 (NSW 92780).

\section{Grevillea quadricauda $P$. Olde $\mathcal{E}$ N. Marriott, sp. nov.}

A Grevillea arenaria foliis brevioribus infra sparse tomentoso-villosis, perianthio intus super barbam sericeo, nectario glabro, fructibus ad pedicellos horizontalibus cum stylis infractis ad basin; a Grevillea masonii perianthio oblongo cum cauda limbi longiore, barba intra perianthium prope basin posita, pistillis paulo longioribus distinguitur.

HolotyPE: QuEENSLAND: Moreton: Helidon Hills, N. McCarthy s.n., 16 Aug 1992 (NSW). Isotypes: BRI, CANB, K, MEL, US.

Dense, bushy shrubs 1-2 m high with pink-purple new growth; branchlets slender, rounded, white tomentose-villous. Leaves $1.3-1.8 \mathrm{~cm}$ long, $0.3-0.6 \mathrm{~cm}$ wide, narrowly obovate to oblong- elliptic, shortly petiolate, simple, the apex obtuse-mucronate with mucro $0.5-1 \mathrm{~mm}$ long; upper surface pubescent to loosely villous, finely granular to scabrous, the midvein, lateral veins and reticulum slightly raised; margin entire, shortly recurved to almost flat; lower surface openly tomentose-villous, the midvein prominently raised in the proximal half, obscure in the distal half; texture papery. Conflorescence erect, usually terminal, rarely axillary, subsessile, simple, 2-4 flowered; peduncles scarcely evident; floral rachis 1-2 mm long, tomentose; floral bracts $1 \mathrm{~mm}$ long, $0.3 \mathrm{~mm}$ wide, narrow-triangular with attenuate apex, brown-villous, usually persistent to anthesis. Flowers in bud aligned parallel to the rachis, ultimately acroscopic with development basipetal; pedicels $5-15 \mathrm{~mm}$ long, loosely villous; torus 1.5-1.8 $\mathrm{mm}$ across, straight to oblique c. $30^{\circ}$; nectary glabrous, U-shaped, the margin smooth to slightly undulate; perianth $10-11 \mathrm{~mm}$ long, $2.5-3 \mathrm{~mm}$ wide, oblong below the curve with a slight basal dilation ventrally, openly tomentose outside, the tepals with a prominent midrib, detaching soon after anthesis, bearded inside $2.5-3 \mathrm{~mm}$ from the base, the hairs reflexed and extending over the basal glabrous cavity, glabrous or sparsely sericeous above the beard to the limb; limb $3 \mathrm{~mm}$ long, $3 \mathrm{~mm}$ wide, ovoidacuminate, loosely tomentose, the segments faintly ribbed, the apex of each segment drawn into an appendage 1.5-2 mm long; pistil 25-27 mm long; ovary $2 \mathrm{~mm}$ long, 2 $\mathrm{mm}$ wide, sessile, villous, the longest hairs c. $1 \mathrm{~mm}$ long; style straight to slightly inflected just above the ovary, openly villous, the indumentum sometimes extending onto the style-end; pollen-presenter $2.2 \mathrm{~mm}$ long, $1 \mathrm{~mm}$ wide, lateral, oblong-elliptic, \pm flat with a crenulate margin; stigma subapicaloff-centre. Fruit $15-18 \mathrm{~mm}$ long, 5 $\mathrm{mm}$ wide, very oblique to horizontal to the pedicel with the suture directed outwards, ovoid to oblong-ellipsoid, costate, sometimes faintly so, sparsely tomentosepubescent to loosely villous; style persistent, strongly inflected; pericarp $0.5 \mathrm{~mm}$. thick. Seed $10 \mathrm{~mm}$ long, $3.5 \mathrm{~mm}$ wide, obovoidal with a subapical cushion-like swelling and with strongly revolute margins, one bearing a narrow, waxy border extending into an apical wing c. $2 \mathrm{~mm}$ long; outer face convex, longitudinally wrinkled, sparsely pubescent; inner face flat, aculeolose with faint, longitudinal ridge in the centre. Figure 2.

EPITHET: Latin, quadri, four, cauda, tail, in reference to the four tail-like appendages on the perianth limb. 
FLOWER COLOUR: Perianth green with a pinkish-red or white limb; style green.

Flowering Period: August-September.

Distribution: South-eastern Queensland; where it is confined to the Helidon HillsMurphys Creek area and northern New South Wales where it is known only from near Whiporie in the Mt Neville Nature Reserve.

Conservation Status: 3VC suggested.

HABITAT AND ECOLOGY: Grows in gravelly loam or in sand as an undershrub in Eucalypt woodland usually along creek or drainage lines.

Discussion: Grevillea quadricauda is most closely related to G. masonii, which differs in its low-growing, lignotuberous habit, its conflorescences usually with more flowers (6-10), its perianth saccate with the beard positioned higher on the inner surface and with shorter tepal-limb appendages $(<1 \mathrm{~mm}$ long) and slightly shorter pistils (18-24 $\mathrm{mm}$ ). G. quadricauda has slender, weeping branchlets and bright purple-pink new growth while G. masonii has erect, relatively stiff branchlets and green new growth. G. arenaria differs in its usually longer leaves with a densely hairy undersurface, its inner perianth surface with a dense spreading indumentum above the beard, and in its erect fruits with the style erect. Queensland collections of this taxon were placed by McGillivray in G. arenaria subsp. arenaria.

VARIATION: A relatively uniform species.

Selected Specimens: (11 examined): Queensland: Moreton: Murphys Creek, Lord 4/44, (BRI); Helidon Hills, 4 mi NW of Helidon, P. Baxter 1086 \& Lebler, 4 Sep 1968 (BRI); Helidon Hills,
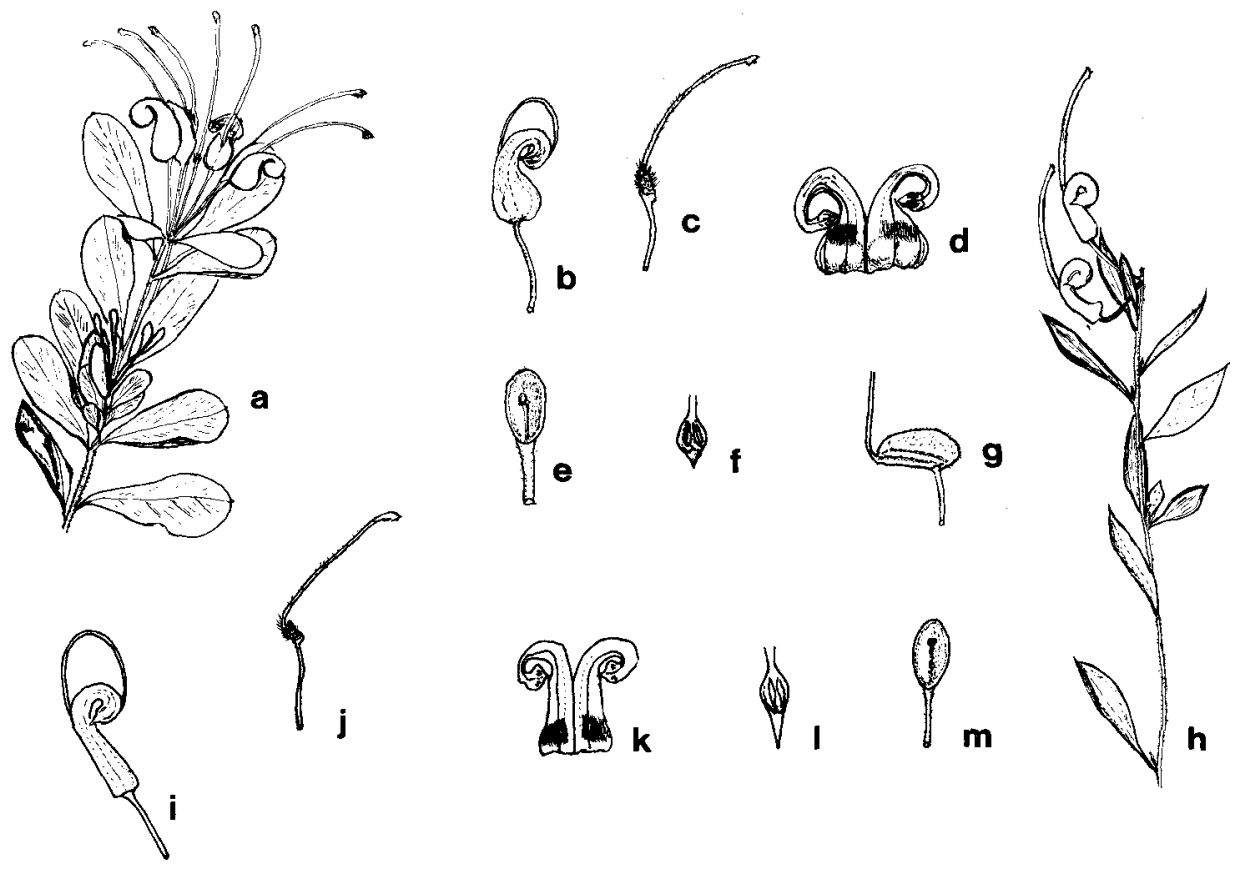

Figure 2. a-g, G. masonii a. Habit (x0.5); b. Perianth before anthesis (x1); c. Pistil (x1); d. Inner perianth (x1); e. Tepal-limb showing appendage (x2.5); f. Pollen-presenter (x3.5); g. Fruit (x0.5). g-m,G. quadricauda g. Fruit (x0.5) h. Habit (x0.5); i. Perianth before anthesis (x1); j. Pistil (x1); k. Inner perianth $(x 1)$; 1. Tepal-limb showing appendage $(x 2.5)$; $\mathbf{m}$. Pollen-presenter $(x 3.5)$. 
Olde s.n., 20 Aug 1987 (NSW). New South Wales: North Coast: Cabbage Tree Ck, Mt Neville Nature Reserve, SW of Rappville, Olde 93/49 \& D. Mason, 4 Sep 1993 (NSW, BRI).

\section{Grevillea rhizomatosa $P$. Olde $\mathcal{E} N$. Marriott, sp. nov.}

A Grevillea arenaria perianthio intus glabro vel sparse sericeo supra barbam, nectario glabro, fructibus carentibus distinguitur.

HolotyPE: New South WALes: North Tablelands: Mulligans Hut, Dandahra Creek, Gibraltar Range National Park, P. Olde 92/101, 21 Sep 1992 (NSW). Isotypes: BRI, CANB.

Root-suckering, bushy shrub 0.3-1 m high; branchlets slender, terete, brown-villous. Leaves yellowish-green, $0.7-2.7 \mathrm{~cm}$ long, $0.7-1.2 \mathrm{~cm}$ wide, obovate to oblong-elliptic, shortly petiolate, simple, the apex obtuse-mucronate with mucro c. $0.5 \mathrm{~mm}$ long; upper surface convex, smooth to slightly rough, glabrous or with a few scattered, appressed hairs, the midvein, lateral veins and reticulum prominently raised; margin entire, shortly recurved to almost flat; lower surface bearing a dense matted indumentum of short hairs overlain by a sparse indumentum of long, appressed hairs with brownish contents, the midvein and also sometimes a few lateral veins prominently raised; texture firmly chartaceous. Conflorescence erect, terminal, subsessile, simple, 2-4-flowered; peduncles absent; floral rachis 2-3 mm long, brown-villous; floral bracts $2 \mathrm{~mm}$ long, $0.5 \mathrm{~mm}$ wide, narrow-triangular with attenuate apex, brownvillous outside, closely appressed to the rachis between the pedicels, usually persistent to anthesis. Flowers ascending in bud; pedicels $5 \mathrm{~mm}$ long, villous; torus $1.2 \mathrm{~mm}$ across, straight to very slightly oblique; nectary glabrous, arcuate, the margin undulate; perianth $10 \mathrm{~mm}$ long, $2.5 \mathrm{~mm}$ wide, oblong below the curve with slight ventral dilation, openly tomentose outside, the tepals with prominent midrib, detaching soon after anthesis, inconspicuously bearded inside $1-1.5 \mathrm{~mm}$ from the glabrous base, the hairs reflexed, glabrous or with scattered appressed trichomes above the beard to the limb; limb $3 \mathrm{~mm}$ long, $3 \mathrm{~mm}$ wide, ovoid, densely tomentose, the segments prominently ribbed to the apex, the apex drawn into a densely hairy appendage $2.5 \mathrm{~mm}$ long; pistil $24 \mathrm{~mm}$ long; ovary $1.5 \mathrm{~mm}$ long, $1.2 \mathrm{~mm}$ wide, sessile, villous, the hairs appressed to slightly spreading, the longest hairs c. $1 \mathrm{~mm}$ long; style straight, bearing an untidy, moderately sparse indumentum of appressed and ascending hairs, the indumentum extending onto the style-end; pollen-presenter $2-2.2 \mathrm{~mm}$ long, 1.5-2 $\mathrm{mm}$ wide, lateral, obovate to almost round, \pm flat with a crenulate margin; stigma central to slightly distally off-centre with a prominent ridge from the stigma to the base of the pollen-presenter. Fruit \& seeds not seen. Figure 3.

EPITHET: Latin, rhizomatosus, bearing a rhizome, in reference to the root-suckering habit of this species.

Flower Colour: Perianth green at the base, dull pink on the limb; style green.

Flowering Period: Spring.

Distribution: New South Wales; confined to a few localities in Gibraltar Range National Park.

CONSERvation Status: 2EC suggested. The species occurs in scattered populations along the track from Mulligan's Hut towards the highway and at the nearby Waratah trig (R. Paine pers. comm.). Further investigation of its distribution is needed.

Habitat AND ECOLOGY: Grows in sandy soils in sclerophyll eucalypt forest, usually near creek lines.

Discussion: Differs from Grevillea arenaria in its inner perianth surface glabrous or sparsely sericeous above the beard, its glabrous nectary. G. arenaria usually possesses a much larger pollen-presenter (up to $4 \mathrm{~mm}$ long, 2-3 $\mathrm{mm}$ wide) and has the stigma distally off-centre. The complete absence of fruits and seeds on G. rhizomatosa 
suggests that this species regenerates entirely by root suckers and it is therefore considered to be reproductively isolated. It is readily distinguished by its almost round, strongly convex leaves and by the dense matted indumentum of the leaf undersurface. Other new and related species here described (G. banyabba, G. masonii, G. quadricauda) differ in having the lamina of the leaf undersurface visible through the indumentum. McGillivray (1993) placed specimens of this taxon in his G. arenaria subsp. arenaria.

VARIATION: A relatively uniform species.

Selected Specimens ( 5 examined): New South Wales: Northern Tablelands: Dandahra Creek near Mulligans Hut, Gibraltar Range National Park, K. Wilson 819 \& Johnson, 21 Nov 1975 (NSW); Gibraltar Range National Park, Grieves, 27 Oct 1968 (NSW).

\section{Grevillea montana $R, B r$.}

(Brown 1810: 172).

G. arenaria subsp. montana (R. Br.) McGillivray (McGillivray 1986: 1)

Type Citation: 'In Novae Hollandiae ora orientali; prope Port Jackson: in montosis.'

LECTOTYPE (McGillivray 1993: 405): 15 Grevillea montana Gathered in Mr Baralliers Journey [R. Brown's script]; also labelled 'R. Brown, Iter Australiense, 1802-5. No. 3326 (BM - photo seen - two pieces at the upper right of the sheet). Isolecto: BM (n.v.).

Bushy, lignotuberous shrub 0.5-1.5 m high; branchlets slender, terete, sericeous. Leaves 1.5-3 cm long, 1-6.5 mm wide, narrow-obovate to narrow-elliptic, rarely linear, shortly petiolate, simple, the apex usually acute, the mucro c. $0.5 \mathrm{~mm}$ long; upper surface coarsely granular, sometimes wrinkled, glabrous or with a few scattered, appressed hairs, the midvein, lateral veins and reticulum slightly raised; margin entire, strongly revolute; lower surface usually partially obscured by the margin, sericeous with obscure to prominent midvein; texture papery. Conflorescence erect, terminal, subsessile, simple, 1-4-flowered; peduncles absent; floral rachis 1-3 $\mathrm{mm}$ long, sericeous; floral bracts $0.5-1 \mathrm{~mm}$ long, $0.3 \mathrm{~mm}$ wide, narrow-triangular with attenuate apex, sericeous outside, usually persistent to anthesis and appressed between the pedicels to the rachis. Flowers in bud erect, ultimately adaxially orientated; pedicels $7.5-8 \mathrm{~mm}$ long, sparsely sericeous; torus $1.5-1.8 \mathrm{~mm}$ across, oblique c. $40^{\circ}$; nectary arcuate to
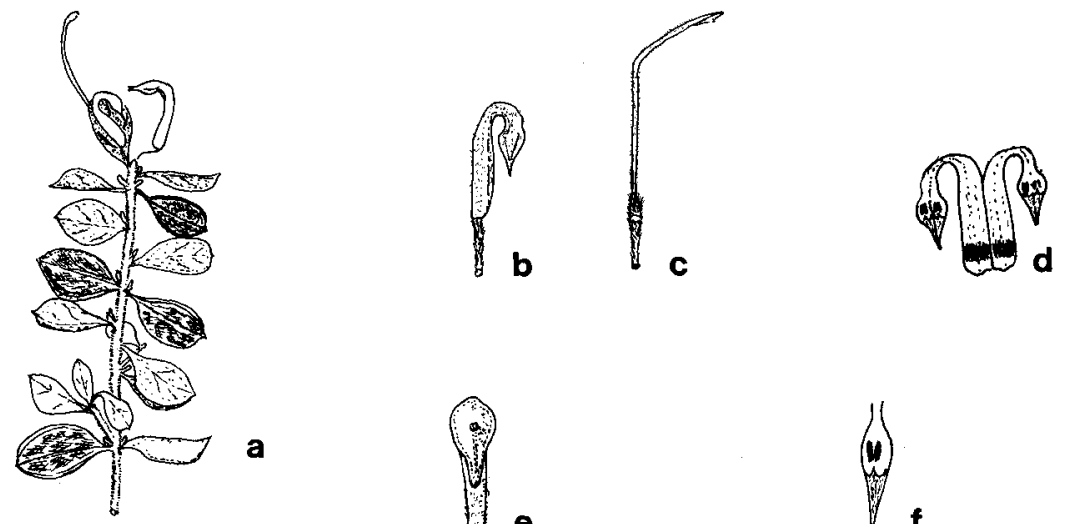

a

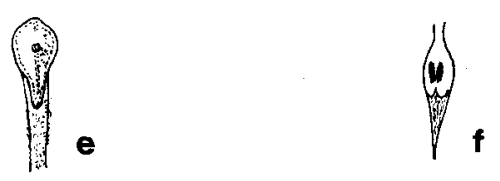

Figure 3. G. rhizomatosa a. Habit (x0.5); b. Perianth before anthesis ( $\mathrm{x} 1)$; c. Pistil (x1); d. Inner perianth (x1); e. Tepal-limb showing appendage (x3); f. Pollen-presenter (x3). 
reniform, conspicuous; perianth $10 \mathrm{~mm}$ long, $3.5 \mathrm{~mm}$ wide, erect till late bud, oblong with slight basal dilation, sparsely tomentose outside, the tepals with a prominent midrib, detaching soon after anthesis, bearded inside c. $3 \mathrm{~mm}$ from the base, the hairs reflexed and extending over a basal glabrous cavity, sparsely sericeous above the beard to the limb on the ventral tepals; limb $3 \mathrm{~mm}$ long, $3 \mathrm{~mm}$ wide, revolute at anthesis, angularly ovoid-acuminate, loosely tomentose, the segments prominently ribbed to the apex, the apex drawn into an appendage 1-1.5 mm long; pistil 23-24 $\mathrm{mm}$ long; ovary $2 \mathrm{~mm}$ long, $2 \mathrm{~mm}$ wide, sessile, appressed-villous, the longest hairs c. $1 \mathrm{~mm}$ long; style straight to slightly incurved, loosely villous, the hairs coarse and c. $1 \mathrm{~mm}$ long, the indumentum extending onto the style-end; pollen-presenter 2-2.2 $\mathrm{m}$ long, $1.5 \mathrm{~mm}$ wide, lateral, obovate, \pm flat; stigma distally off-centre. Fruits $10-12 \mathrm{~mm}$ long, $7 \mathrm{~mm}$ wide, erect, ellipsoidal, loosely villous, faintly ribbed, with erect style. Seeds not seen.

FLOWER COLOUR: Perianth green with reddish limb; style green.

Flowering Period: August-October.

Distribution: New South Wales, where confined to the southern part of the Hunter Valley from Denman to Kurri Kurri.

Conservation Status: Suggested 2VC.

HaвiтAт \& Ecology: Grows in sandy soil in open eucalypt forest, near or at the top of ridges.

Discussion: G. montana differs from G. arenaria in the lack of a spreading indumentum above the beard on the inner perianth surface, in its sessile, few-flowered conflorescences, in its villous style, in its generally narrower leaves and in its less prominently ribbed fruits. It differs from most forms of subsp. arenaria in its silky leaf undersurface.

VARIATION: This species is relatively uniform in its morphology.

Selected SPecimens (25 examined): New South Wales: North Coast: near Apple Tree Flat on Nielsens Ck (tributary of Hunter) Jerrys Plains area, J. Kennedy, 26 Sep 1962 (NSW); $6.4 \mathrm{~km} \mathrm{SE}$ of Bulga on Milbrodale-Broke Rd, Coveny 5592 \& Jacobs, 16 Sep 1974 (NSW, BRI); Black Hill, between Maitland and Newcastle, A. Martin, Jun 1979 (NSW); North Rothbury, near Branxton, Phillips 361, 21 Sep 1962 (NSW, CBG); Greta, Boorman, Nov 1904 NSW 92649; $0.8 \mathrm{~km}$ S of Pelaw Main P.O. towards Cooranbong, Coveny 7383, 8 Mar 1976 (NSW, PERTH); 2 miles [3 km] E of Kurri Kurri, McGillivray 1388, 20 Sep 1965 (NSW92779). Central Western Slopes: Denman, Heron, Sep 1908 (NSW 92642).

\section{Grevillea obtusiflora $R . B r$.}

(Brown 1830: 19).

Holotype: New South Wales: Central Tablelands: Brushy hills north of Bathurst 1822, Cunningham 197 (BM n.v.). Isotype: K (n.v.).

A root-suckering, many-stemmed shrub $0.2-0.3 \mathrm{~m}$ high; branchlets rounded, tomentose. Leaves $2-4 \mathrm{~cm}$ long, $0.2-0.5 \mathrm{~cm}$ wide, ascending, sessile, simple, narrowly elliptic to obovate, obtuse-mucronate to acute at the apex; upper surface coarsely granulate (granules c. $0.05 \mathrm{~mm}$ diam.), villous when young but soon \pm glabrous, midvein scarcely evident; margin entire, smoothly recurved to revolute, sometimes strongly so on dried specimens; lower surface either villous with loose, ascending hairs or sericeous, midvein prominent. Conflorescence erect, usually terminal, subsessile to very shortly pedunculate, simple or 1-3 branched at the base; unit conflorescence 610-flowered, secund to umbel-like, relatively loose to dense with development basipetal; peduncles $0-3 \mathrm{~mm}$ long, $0.7-1 \mathrm{~mm}$ thick, sericeous; floral rachis $2-4 \mathrm{~mm}$ long, sericeous; floral bracts $0.5-1 \mathrm{~mm}$ long, narrow-ovate, silky outside, a few usually 
persistent to anthesis. Flowers acroscopic; pedicels 3-5.5 $\mathrm{mm}$ long, sericeous; torus 1$1.5 \mathrm{~mm}$ across, oblique at c. $40^{\circ}$; nectary conspicuous, reniform; perianth $8-9 \mathrm{~mm}$ long, $4 \mathrm{~mm}$ wide, persistent, coherent with strong inter-tepal adherence, ribbed, oblong-ovoid, slightly dilated at the base, loosely tomentose outside, bearded inside adjacent to the ovary, glabrous elsewhere; limb strongly revolute, subcubic with depressed apex, sericeous, the segments prominently carinate; pistil (18-)20-23 mm long; stipe absent to $0.2 \mathrm{~mm}$ long; ovary c. $2 \mathrm{~mm}$ long, villous; style loosely and coarsely villous; style-end 1.2-1.4 mm thick; pollen-presenter $1.5-2 \mathrm{~mm}$ long, $1.5-2$ $\mathrm{mm}$ wide, lateral, convex, round; stigma obscure, central to slightly off-centre distally. Fruit \& seeds not seen.

FLOWER COLOUR: Perianth pink with creamy-white limb. Style deep pink.

FLoWERING PERIOD: Winter-Spring.

Distribution: New South Wales, Central Tablelands, Clandulla near Kandos. Cunningham's collection from north of Bathurst is from a different population but its exact location is unknown.

Conservation Status: 2E. This species is only known with certainty from the Clandulla State Forest, where it occurs in scattered colonies.

Habitat And ECOlOgy: Grows in sandy loam soils in open, low scrub beneath eucalypt forest. Reproduction is from root-sucker. Fruits have not been observed.

VARIATION: The indumentum on the leaf undersurface varies from sericeous to villous but the species is otherwise relatively uniform in its morphology.

Notes: The features that best summarise G. obtusiflora s. str. are: low-growing, rootsuckering habit; leaves coarsely granular on the upper surface usually with shortly recurved margins; conflorescences erect, few-flowered with rachis 1-3 $\mathrm{mm}$ long, caducous floral bracts $<1 \mathrm{~mm}$ long; perianth pinkish-red with cream limb, persistent long after anthesis and with strong inter-tepal adherence; pistils mostly 20-23 mm long with ovary c. $2 \mathrm{~mm}$ diam with long, bristling hairs; style coarsely villous; pollenpresenter round, convex, bearing only scattered pollen grains at anthesis and with an obscure, slightly depressed stigmatic cavity. Although these populations are selfreproducing, they fail to set fruit and must therefore be considered reproductively isolated.

Selected Specimens (5 examined): New South Wales: Central Tablelands: $0.4 \mathrm{~km}$ from Clandulla, Clandulla State Forest, Coveny 9563, 24 Sep 1977 (NSW); Clandulla State Forest, Olde 93/61-62, 1 Oct 1993 (NSW).

\section{Grevillea kedumbensis (McGillivray) P. Olde $\mathcal{E} N$. Marriott, comb. et stat. nov.}

BasionYM: G. obtusiflora subsp. kedumbensis McGillivray, New Names in Grevillea: 11 (1986).

Holotype: New SOuth Wales: Central Tablelands: at bottom of Kedumba Valley, $8 \mathrm{~km}$ beyond homestead, A. M. Blombery, 7 Oct 1977 (NSW 117349).

ILLUSTRATIONS: Blombery \& Maloney 1992: 76-77; McGillivray 1993: 265.

A lignotuberous, twiggy shrub $0.2-1 \mathrm{~m}$ high; branchlets slender, round to slightly angular, glabrous to silky or sparsely so. Leaves $1-3 \mathrm{~cm}$ long, $0.1-0.5 \mathrm{~cm}$ wide, ascending, shortly petiolate, simple, narrowly elliptic to obovate, obtuse-mucronate, the mucro c. $1 \mathrm{~mm}$ long; upper surface glabrous to sparsely sericeous, coarsely granulate (granules c. $0.05 \mathrm{~mm}$ diam.), densely to sparsely distributed, midvein evident; margin entire, usually strongly revolute on dried specimens; lower surface sericeous, midvein prominent. Conflorescence erect, terminal or axillary in the upper axils, subsessile to shortly 
pedunculate, simple or 1-3 branched at the base; unit conflorescence 12-20 flowered, relatively loose, subglobose to shortly cylindrical, with development basipetal; peduncles 0-3 mm long, sericeous; floral rachis 2-5 mm long, $0.8 \mathrm{~mm}$ thick, sericeous; floral bracts $1.5-3.5 \mathrm{~mm}$ long, narrow-triangular, sparsely silky to glabrous outside, glabrous inside, mostly persistent to anthesis; nectary conspicuous, reniform. Flowers acroscopic; pedicels 3-6 mm long, loosely tomentose to glabrous, usually retrorse; torus c. $1 \mathrm{~mm}$ across, oblique at c. $40^{\circ}$; perianth $6-7.5 \mathrm{~mm}$ long, $2.5-3 \mathrm{~mm}$ wide, deciduous soon after anthesis, cohering except along the dorsal suture, ribbed, oblong-ovoid, \pm glabrous to loosely tomentose outside, bearded inside adjacent to and above the ovary for c. $2 \mathrm{~mm}$, glabrous or with scattered trichomes elsewhere; limb strongly revolute, obtuse-subcubic, loosely tomentose or with scattered hairs only, the segments prominently carinate; pistil $12.5-17.5 \mathrm{~mm}$ long; stipe absent to $0.2 \mathrm{~mm}$ long; ovary c. $2 \mathrm{~mm}$ long, villous; style pubescent to loosely and finely villous, usually with several short, erect trichomes interspersed; style-end $0.8 \mathrm{~mm}$ thick; pollen-presenter 1.5-2 mm long, 1.5-1.8 mm wide, lateral, flat to slightly convex, round to obovateelliptic; stigma prominent, distally off-centre, slightly oblique. Fruits $13-15 \mathrm{~mm}$ long, 5-6 mm wide, erect, ovoid, sparsely tomentose, very faintly ribbed; style persistent, erect; pericarp $0.3-0.5 \mathrm{~mm}$ thick at the suture. Seed $8.5 \mathrm{~mm}$ long, $2.5 \mathrm{~mm}$ wide, ellipsoid with a subapical dilation and apical excurrent wing c. $1 \mathrm{~mm}$ long; outer face convex, smooth, minutely pubescent; inner face flat; margin revolute with a narrow, membranous wing along one side.

Flower Colour: Perianth green to cream; style pink to dull red; style-end green.

FLowering PERIOD: Scattered flowers all year with a winter-spring peak.

Distribution: New South Wales, Central Tablelands, where restricted to an area between the Kedumba Valley and Scotts Main Range (near Yerranderie).

CONSERVATION Status: Recommended 2KC. There are specimens from several populations but these are relatively poorly known. Apparently different locations may prove to have been sampling the same population. Much of the country in which this species is distributed is rugged and difficult to access.

Habitat \& Ecology: Grows in sandy loam mixed with laterite in dry sclerophyll forest. Regeneration is from seed and lignotuber. Pollinator uncertain, probably nectarivorous birds.

VARIATION: Plants from Kedumba Valley achieve a height of up to $1 \mathrm{~m}$ whereas plants from Scotts Main Range rarely grow more than $0.2-0.3 \mathrm{~m}$ high.

Notes: In the diagnosis of G. obtusiflora subsp. kedumbensis, McGillivray (1986: 11) notes two features through which separation from subsp. obtusiflora can be made, viz. a sericeous leaf undersurface and shorter pistils (pistils $<18 \mathrm{~mm}$ long). The leaf discontinuity is not supported by more recent collections of G. obtusiflora s.str., most of which have a sericeous leaf undersurface. However, McGillivray (1993: 265) cites further discontinuities in its lignotuberous habit (many-stemmed and up to $1 \mathrm{~m}$ high), its thinner style-end and the stronger degree of leaf recurvature. We would further add differences in its flower colour, larger number of flowers per conflorescence, quickly deciduous perianth and decreased degree of inter-tepal adherence, longer and more sparsely hairy floral bracts (1.5-3.5 $\mathrm{mm}$ long), smaller perianth ( 7 $\mathrm{mm}$ long, c. $3 \mathrm{~mm}$ wide), finer and shorter trichomes on the style, shape of pollenpresenter (usually flat) and increased prominence of stigma, an observed marked capacity to transfer pollen, and high degree of fruit-set.

The degree of approach of some collections of G. kedumbensis to the Picton-Thirlmere phenotype of $G$. mucronulata suggests that $G$. kedumbensis is as closely related to 
G. mucronulata as to G. obtusiflora. While G. mucronulata differs in its stylar indumentum and flower size (larger perianth and longer pistils) and has a diagnostic inflection of the style on its fruits, only the closest inspection can separate specimens of $G$. kedumbensis (e.g. Kennedy 22 et al.) from G. mucronulata when fruits are lacking.

Most specimens of $G$. kedumbensis also show a strong morphological similarity to some phenotypes of $G$. floribunda, in particular the 'delicate form' sensu McGillivray. However, they differ in the degree of nectary prominence, position of perianth beard, colour of stylar indumentum, rachis length and granulosity of the upper leaf surface.

Grevillea aff. kedumbensis. Two plants in Castlereagh State Forest in western Sydney (e.g. Olde 93/53., B. Walters s.n.) show a strong approach to G. kedumbensis but differ in their glabrous leaf undersurface, slightly longer pistils $(18-20 \mathrm{~mm})$ and in their longer, decurved, glabrous floral rachises. The possibility that these plants represent a separate distinct taxon is high as they occur in weed-free bushland. However, given the number of plants involved and their occurrence beside a track (albeit several hundred metres apart), the possibility that they are of hybrid origin cannot be excluded. G. mucronulata occurs sympatrically and is a possible parent. Until further field studies are conducted and the pollen is examined, we recommend a cautious approach to the circumscription of this taxon.

Selected Specimens ( 7 examined): New South Wales: Central Tablelands: $3.6 \mathrm{~km}$ S of Mt Cookem, Scotts Main Range, Blue Mountains National Park, M. Kennedy 22, Cuneo E Fairley, 3 Oct 1990 (NSW); Kedumba Valley, $1.6 \mathrm{~km} \mathrm{~S}$ of Reedy Ck, Kedumba Valley, $15 \mathrm{~km} \mathrm{~S}$ of Wentworth Falls, Johnson \& D. Benson, 8 Oct 1982 (NSW, K, US); eastern slope of Mt Solitary, Kedumba Valley, Willows NSW 92639, 12 Aug 1950 (NSW); The Cedar Track, near Kiaromba Ridge to Devitts Range, Coxs River to Kowmung River, Johnson, 26 Mar 1951 (NSW 15640).

\section{Grevillea granulifera (McGillivray) Olde \& Marriott, comb. et stat. nov.}

BAsIonyM: G. obtusiflora subsp. granulifera McGillivray, New Names in Grevillea: 11 (1986).

Holotype: New South Wales: North Coast: 1-2 km west of Mt George, L.A.S.Johnson 8518, 26 Jan 1980 (NSW). Isotype: K (n.v.).

A rounded, dome-shaped shrub to $1 \mathrm{~m}$ or an erect virgate shrub to $4.5 \mathrm{~m}$ with ascending branches; branchlets angular to rounded, tomentose. Leaves $1.5-6 \mathrm{~cm}$ long, $0.2-1.1 \mathrm{~cm}$ wide, ascending, petiolate, simple, elliptic; apex obtuse-mucronate; upper surface convex, finely granulose (granules $0.02 \mathrm{~mm}$ diam.), faintly wrinkled, silky, soon glabrous, midvein and intramarginal veins evident to obscure; margin entire, revolute or recurved; lower surface silky, midvein prominent. Conflorescence strongly decurved or deflexed at the base of the peduncle, shortly pedunculate, usually terminal on short branchlets, sometimes axillary or cauline, simple or few-branched with development basipetal; unit conflorescence secund, rarely exceeding the foliage, dense, (8-)12-16 flowered; peduncles 3-10 mm long, 0.5-0.8 mm thick, bracteate, tomentose-silky; floral rachises 2-13 $\mathrm{mm}$ long, tomentose; floral bracts $1.5-2.5 \mathrm{~mm}$ long, narrow-triangular, tomentose outside, falling just before anthesis. Flowers acroscopic; pedicels 3-7 mm long, loosely villous; torus $1.5-2 \mathrm{~mm}$ across, straight to slightly oblique, squarish; nectary subreniform; perianth $8-9 \mathrm{~mm}$ long, 3-4 mm wide, oblong-ovoid, dilated at the base, detaching soon after anthesis, ribbed, sparsely tomentose outside, densely bearded inside just above the dilation, sparsely villous to the limb, coherent except along the dorsal suture before anthesis; limb revolute, loosely villous, subcubic, the segments carinate; pistil 21-24 mm long; ovary sessile, oblong-ovoid, scarcely wider than the style, white appressed-villous; style slightly inflexed just above the ovary, sparsely tomentose, at first exserted towards the base 
on the dorsal side and looped upwards before anthesis, straight to gently incurved after, terminated by a broad, flattened style-end; style-end $0.7-0.9 \mathrm{~mm}$ thick; pollenpresenter $2.5 \mathrm{~mm}$ long, $2 \mathrm{~mm}$ wide, lateral, flat, obovate with a short basal attenuation; stigma prominent, distally off-centre. Fruit $14 \mathrm{~mm}$ long, $5.5 \mathrm{~mm}$ wide, erect, narrow-ellipsoid, prominently ribbed, sparsely tomentose; style persistent, erect; pericarp c. $0.3 \mathrm{~mm}$ thick. Seed $8 \mathrm{~mm}$ long $2.5 \mathrm{~mm}$ wide, oblong-ellipsoid with an apical wing $2 \mathrm{~mm}$ long; upper surface convex with subapical dilation, minutely pubescent; lower surface flat; margin revolute, narrowly winged along one side.

FLOWER COLOUR: Perianth pale to dark pinkish-red or pinkish-purple at the base with a creamy-white limb; style burgundy-red or brownish-red with green pollen-presenter.

Flowering Period: September-January.

Distribution: New South Wales, North Coast and Northern Tablelands, from near Wingham in the north to Polblue Creek, Barrington Tops State Forest in the south extending north-west to Wollomombi Falls. Note: the locality Gloucester Tops cited by McGillivray (1993: 266) is incorrect and results from an erroneous locality given by the collector, P. Lightfoot. (P. Lightfoot pers. comm.). The specimen was in fact collected at Polblue Creek.

Conservatron STATUS: 3KC. Poorly known and rarely collected. Most populations are extremely restricted in size and occur often as scattered remnants in country that is being gradually cleared for agriculture and grazing.

HABITAT \& ECOLOGY: Inhabits ridge-tops and hillsides in open forest. Most collections have been from poor, stony serpentine soils but at Polblue Creek, the soils are decomposed granite sand. Regeneration after fire is from seed. Wattle-birds, friar-birds and miners have been seen probing the flowers at Mt. George (pers. obs.) and are presumed pollinators.

VARIATION: There appear to be at least two distinct forms of G. granulifera. Specimens from the type locality and elsewhere have strongly erect branches and floral rachises 10-13 mm long (average 12-14 flowers), and leaf undersurface with a dense sericeous indumentum whereas specimens from Wollomombi have slender, weeping branchlets, floral rachises (2-)3-5 mm long (average 6-10 flowers), and a moderately dense, slightly loose, subsericeous leaf undersurface. Field study of all populations is necessary before infraspecific ranking of the forms can be considered.

NoTES: McGillivray (1986: 11) distinguished G. obtusiflora subsp. granulifera from other subspecies of $G$. obtusiflora by its robust habit, its finely granular upper leaf surface and its flattened style-end. McGillivray (1993: 264) further observes that G. obtusiflora subsp. granulifera differs from these subspecies in its single-stemmed habit and its leaves sericeous on the undersurface. In addition to these differences we would add decurved to deflexed, terminal, axillary or cauline, pedunculate conflorescences usually with 12-16 flowers and with rachises up to $13 \mathrm{~mm}$ long, deciduous perianth with low degree of inter-tepal adherence, ovary c. $2.5 \mathrm{~mm}$ long, angularly oblong-ovoid with finer, less prominent hairs, pollen-presenter flat, obovate with short basal appendage and prominent stigma, and fruits c. $14 \mathrm{~mm}$ long. It usually occurs on dry ridges in serpentinaceous soils, an unusual soil type in Australia, and the correlation of soil type and morphology presents an association of characters that more or less define it as a species.

G. granulifera is most closely related to G. guthrieana.

Selected Specimens (11 examined): New South Wales: North Coast: 3 miles [5 km] N of Curricabark Creek, Curricabark, Johnson, 15 Oct 1953 (NSW 92768); Watchimbark Creek, c. 80 km NW of Gloucester, Blaxell 3, 21 Sep 1968 (NSW); Burrell Creek area, near Wingham, R. Gray, 14 
Sep 1968 (NSW). Northern Tablelands: Wollomombi Falls, Williams s.n., 20 Nov 1966 (NSW); Polblue Creek, Barrington Tops State Forest, Olde 93/75, Lightfoot, Tame \& Stokes, 14 Oct 1993 (NSW, CBG, BRI).

\section{Grevillea guthrieana $P$. Olde $\mathcal{E} N$. Marriott, sp. nov.}

A Grevillea granulifera ramulis villosis, foliis supra grosse granulosis subtus villosis, florum bracteis mox cadentibus, rhachidibus pedunculisque aut glabris aut sparse hirsutis, pedunculis tenuibus, elongatis (10-22 mm longis), perianthio viridi cum dilatatione subannulari ad basin, pistillis parum longioribus ( $25-26 \mathrm{~mm}$ longis), fructibus longioribus (c. $20 \mathrm{~mm}$ longis) distinguitur.

Holotype: New South Wales: North Coast: $3 \mathrm{~km}$ E of Booral, P. Olde 92/96, 20 Sep 1992 (NSW). Isotype: CANB.

IlLUSTRATION: McGillivray (1993: 264) as G. obtusiflora subsp. granulifera.

Shrub 1.5-2 (-4.5) $\mathrm{m}$ high with spreading, pendulous branchlets; branchlets round, villous when young, soon \pm glabrous. Leaves $2-6 \mathrm{~cm}$ long, $0.4-0.9 \mathrm{~cm}$ wide, ascending, shortly petiolate, simple, soft, oblong-elliptic, obtuse-mucronate; upper surface coarsely granular (granules c. $0.05 \mathrm{~mm}$ diam.), faintly wrinkled, glabrous, the midvein evident; margin entire, loosely revolute; lower surface loosely villous, the lamina clearly visible beneath the indumentum, the midvein prominent. Conflorescence decurved, pedunculate, terminal, simple or 1-branched; unit conflorescence 2-6(-10)flowered, loose with development basipetal; peduncles slender, (7-)10-22 mm long, 0.3-0.4 mm thick, glabrous or sparsely tomentose; rachises 2-6 $\mathrm{mm}$ long, glabrous or sparsely tomentose; floral bracts $1-1.5 \mathrm{~mm}$ long, $0.5 \mathrm{~mm}$ wide, narrow-triangular, glabrous to loosely tomentose outside, caducous soon after bud formation. Flowers acroscopic; pedicels $6 \mathrm{~mm}$ long, with a sparse indumentum of spreading, crisped hairs; torus $2 \mathrm{~mm}$ across, slightly oblique, undulate; nectary reniform to cushion-like, prominent; perianth $9 \mathrm{~mm}$ long, 4-5 $\mathrm{mm}$ wide, oblong with a conspicuous subannular dilation in the basal $2 \mathrm{~mm}$, sparsely tomentose outside, bearded inside c. $2 \mathrm{~mm}$ from the base where the reflexed hairs condensed for c. $2 \mathrm{~mm}$, elsewhere with scattered, appressed hairs or glabrous, the tepals ribbed, deciduous soon after anthesis; limb sparsely tomentose, subcubic, apically depressed, the segments prominently carinate; pistil 25-26 mm long; stipe absent to $0.2 \mathrm{~mm}$ long, glabrous; ovary 2-2.5 $\mathrm{mm}$ long, oblong-ovoid, angular with prominent ribs, pubescent to tomentose-villous, the trichomes c. $0.5 \mathrm{~mm}$ long; style straight, loosely and openly tomentose in the lower third, glabrous or almost so in the distal third; style-end $0.7-0.9 \mathrm{~mm}$ thick; pollenpresenter 2.2-2.5 mm long, $2 \mathrm{~mm}$ wide, obovate with short, basal attenuation, flat to convex with prominent stigma. Fruits $20 \mathrm{~mm}$ long, $5 \mathrm{~mm}$ wide, narrow-ellipsoid with apical attenuation, prominently ribbed, sparsely tomentose; style persistent, erect; pericarp c. $0.4 \mathrm{~mm}$ thick. Seeds $10 \mathrm{~mm}$ long, 2-2.5 mm wide, oblong-ellipsoidal with a subapical dilation and an apical wing 3-4 mm long; upper surface strongly convex, faintly pubescent, otherwise smooth; margins revolute with a narrow waxy border along one side extending into an excurrent apical elaiosome 3-4 $\mathrm{mm}$ long and a short basal wing c. $0.5 \mathrm{~mm}$ long; inner face obscured by the margin. Figure 4 .

EPITHET: Honours Christine Guthrie, née James, (1953- ), horticulturist and bushregenerator. Her voluntary assistance to the authors in the study of Grevillea, in particular her role as Secretary-Treasurer of the Grevillea Study Group and Editor of its Newsletter for many years, is acknowledged.

Flower Colour: Perianth green; style maroon; ovary and pollen-presenter green.

Flowering Period: Spring. 
Distribution: New South Wales, where known from only two locations in the southern part of the North Coast region.

Conservation Status: Recommended 2E. There has recently (1993) been considerable inadvertent damage to the population at Booral through roadworks. This population is very small but may extend beyond the road verge. The second population has not been visited.

Habitat AND Ecology: Grows in sandstone derived loams on creek lines in moist eucalypt forest. Regeneration after fire or disturbance is from seed. Pollinator unknown, probably nectarivorous birds.

NoтEs: Grevillea guthrieana differs from G. granulifera in its villous branchlets and leaf undersurface, its coarsely granular leaf upper surface, its floral bracts falling very early, its floral rachises and peduncles either glabrous or sparsely hairy, its slender elongate peduncles (10-22 $\mathrm{mm}$ long), its green perianth with a subannular basal dilation, its slightly longer pistils and fruits.

Selected Specrmens (10 examined): New South Wales: North Coast: western edge of Carrai Plateau overlooking Kunderang Brook, Grid Ref ML 215875, J. Benson s.n., Aug 1982 (NSW); Booral Creek, Booral-Bulahdelah Rd, Rodd 2355, 28 Sep 1973 (NSW, PERTH).

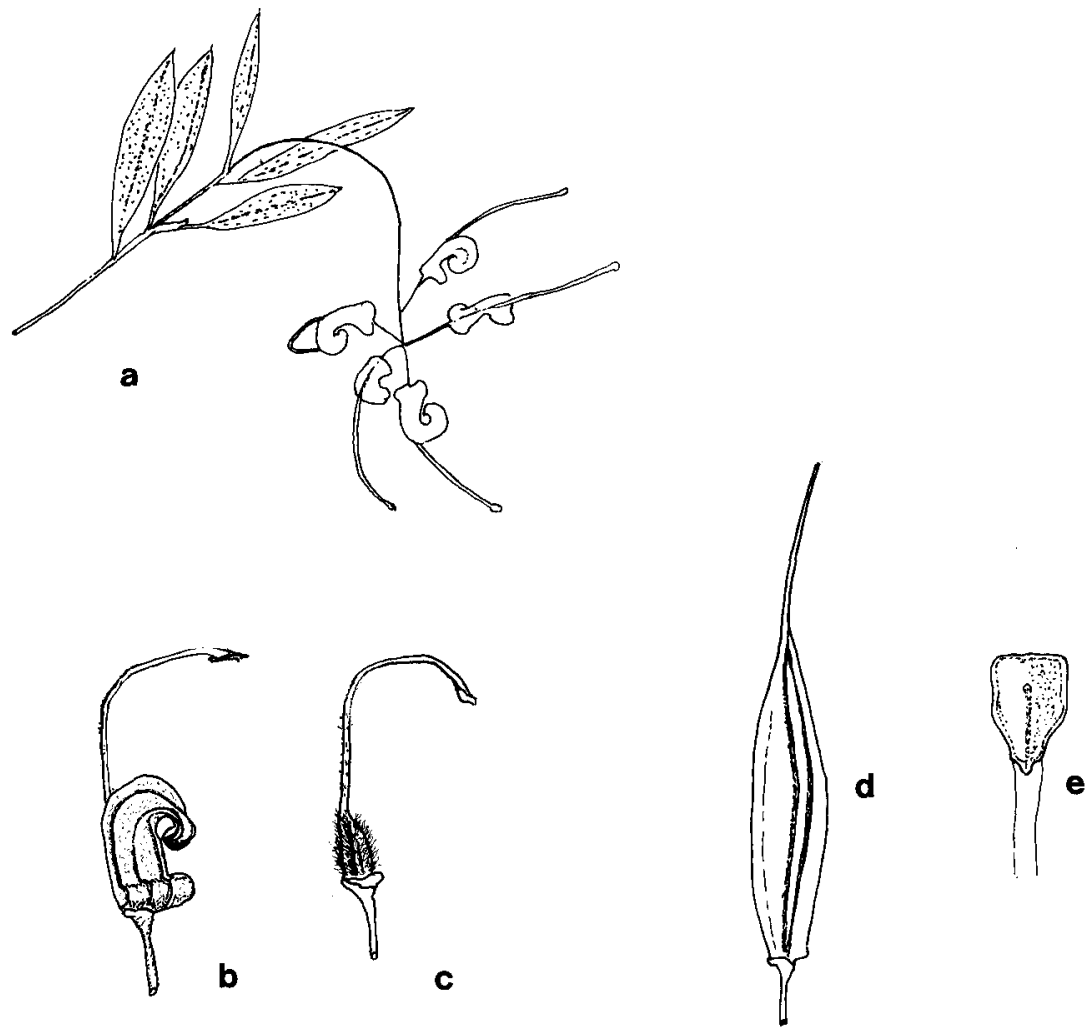

Figure 4. G. guthrieana a. Habit (x0.75); b. Perianth before anthesis (x1.5); c. Pistil (x1.5); d. Pollen-presenter (x3.5); e. Fruit (x1.5). 


\section{Acknowledgements}

We wish to thank the Directors of the following institutions for giving access to their collections as visiting worker: CBG, NSW, BRI, PERTH. Special thanks to Dr. L.A.S. Johnson who critically read earlier drafts of this manuscript. The late Collin Woolcock provided many drawings for use. Heather Clark, Dr. Paddy \& Caryl Lightfoot, David \& Eva Mason, Kevin Stokes, Terry Tame, Brian Walters provided valued assistance with accommodation and field-work in New South Wales as did Mervyn \& Olwyn Hodge and Graham Nosworthy in Queensland. Mr Bill Molyneux and Paul Forster provided information and gave time for discussion. While disagreeing with some of our conclusions, Mr Don McGillivray was, as usual, a most co-operative informant. The Grevillea Study Group of the Association of Societies for Growing Australian Plants provided funds for travelling.

\section{References}

Bentham, G. (1870) Flora australiensis, vol. 5 (Reeve \& Co.: London)

Blombery, A. \& Maloney, B. (1992) The Proteaceae of the Sydney Region. (Kangaroo Press: Sydney).

Briggs J.D. \& Leigh, J.H. (1988) Rare or threatened Australian plants. Austral. Nat. Parks \& Wildlife Service, Special Publication No 14.

Brown, R. (1810) On the Proteaceae of Jussieu. Trans. Linn. Soc. London 10: 15-226.

Brown, R. (1830) Supplementum primum prodromi florae Novae Hollandiae (Richard Taylor: London).

Burbidge, N.T. (1955) An Index to the Microfilm of Robert Brown's Botanical Descriptions (Manuscript) of Australian Plants held by the British Museum (Natural History) (CSIRO: Canberra).

Knight, J. (1809) On the cultivation of the Plants belonging to the Natural Order of Proteeae. (Savage: London).

McGillivray, D.J. (1986) New names in Grevillea. (The author: Castle Hill, N.S.W.)

McGillivray, D.J. (1993) Grevillea. (Melbourne University Press: Melbourne)

Makinson, R.O. (1991) Grevillea. Pp. 31-35 in G. Harden (ed.), Flora of New South Wales, vol. 2. (University of New South Wales Press: Kensington).

Meisner, C.F. (1856) Proteaceae (1) in Candolle A.C. (ed.) Prodromus systematis naturalis regni vegetabilis 14: 209-482.

Olde, P.M. \& Marriott, N.R. (1993a) A taxonomic revision of Grevillea angulata (Proteaceae: Grevilleoideae) and closely related species from the Northern Territory and Western Australia. Telopea 5(2): 399-417.

Olde, P.M. \& Marriott, N.R. (1993b) New species and taxonomic changes in Grevillea (Proteaceae: Grevilleoideae) from south-west Western Australia. Nuytsia 9(2): 237304.

Vallance, T.G. (1990) Jupiter Botanicus in the Bush: Robert Brown's Australian Fieldwork, 1801-5. Proc. Linn. Soc. N.S.W. 112(2): 49-86. 